\title{
Pengaruh Strategi Pengisian Daya Terhadap Kenaikan Beban Puncak Akibat Penetrasi Kendaraan Listrik
}

\section{(Charging Strategy Effect on Peak Load Increase Due to Electric Vehicle Penetration)}

\author{
Boy Ihsan ${ }^{1}$, Deny Hamdani ${ }^{2}$, Nanang Hariyanto ${ }^{3}$
}

\begin{abstract}
To overcome the problem of energy crisis and global warming, many countries in the world are pushing growth in the use of electric vehicles. In the future, the use of electric vehicles in large numbers will also occur in Indonesia and charging electric vehicles will become a new load on the electricity system. One of the effects of electric vehicle penetration is an increase in the system's peak load. Therefore, this study examines how the increase in daily load due to penetration of electric vehicles and how the strategy of electric vehicles charging to reduce the increase in load on one of the electricity systems in Indonesia, namely the Jawa-Bali system. The calculation results show that the Jawa-Bali electrical system is only able to accommodate electric vehicle penetration by $20 \%$ if the problem of losses, instability, and line loading are ignored. In the case of $10 \%$ penetration of electric vehicles, the peak load of the Jawa-Bali system increased by 5,857 MW. However, by scheduling electric vehicle charging, the increase in peak load can be reduced by 3,232 MW and by using the V2G scheme, the energy supplied by the system generator can be reduced by $20,003 \mathrm{MWh}$.
\end{abstract}

Intisari-Untuk mengatasi masalah krisis energi dan pemanasan global, banyak negara di dunia menggalakkan pertumbuhan penggunaan kendaraan listrik. Di masa yang akan datang, penggunaan kendaraan listrik dalam jumlah besar juga akan terjadi di Indonesia dan pengisian daya kendaraan listrik akan menjadi beban baru pada sistem kelistrikan. Salah satu dampak dari penetrasi kendaraan listrik adalah naiknya beban puncak. Oleh karena itu, makalah ini mengkaji kenaikan beban harian akibat penetrasi kendaraan listrik dan strategi pengisian daya kendaraan listrik untuk mengurangi kenaikan beban tersebut pada salah satu sistem kelistrikan di Indonesia, yaitu sistem Jawa-Bali. Hasil perhitungan kenaikan beban menunjukkan bahwa kondisi sistem kelistrikan Jawa-Bali saat in hanya sanggup melayani penetrasi kendaraan listrik sebesar $20 \%$ jika masalah losses, ketidakstabilan, dan pembebanan saluran diabaikan. Pada kasus $10 \%$ penetrasi kendaraan listrik, beban puncak sistem Jawa-Bali naik sebesar 5.857 MW. Namun, dengan menjadwalkan pengisian daya kendaraan listrik pada saat beban rendah, kenaikan beban puncak dapat dikurangi sebesar 3.232 MW dan dengan menggunakan skema V2G, energi yang disuplai oleh pembangkit sistem dapat dikurangi sebesar 20.003 MWh.

Kata Kunci- Kenaikan Beban, Penetrasi Kendaraan Listrik, Sistem Jawa-Bali, Strategi Pengisian Daya, V2G.

1,2,3 Jurusan Teknik Elektro Sekolah Teknik Elektro dan Informatika Institut Teknologi Bandung, Jl. Ganesha 10 Bandung 40132 INDONESIA (e-mail: boyihsan@students.itb.ac.id, deny@power.ee.itb.ac.id,nanang.hariyanto@stei.itb.ac.id)

\section{PENDAhuluan}

Krisis energi dan pemanasan global adalah masalah bersama yang dihadapi oleh negara-negara di dunia. Salah satu aspek yang berkontribusi terhadap kedua masalah tersebut adalah kendaraan bermotor konvensional. Kendaraan bermotor konvensional dalam jumlah yang besar dapat mengonsumsi bahan bakar minyak dan menghasilkan emisi karbon monoksida dalam jumlah yang besar pula. Oleh karena itu, banyak negara di dunia telah menggalakkan perkembangan penggunaan kendaraan listrik untuk membantu mengatasi masalah krisis energi dan pemanasan global.

Penggunaan konsep empat kuadran inverter pada sistem pengisian daya kendaraan listrik nantinya akan memungkinkan kendaraan listrik untuk menyuplai daya ke jaringan, sehingga kendaraan listrik dapat beroperasi dalam dua mode, yaitu mode Grid to Vehicle (G2V) dengan arah daya mengalir dari jaringan ke kendaraan listrik atau biasa dikenal dengan proses pengisian daya (charging), dan mode Vehicle to Grid (V2G) dengan arah daya mengalir dari kendaraan listrik ke jaringan atau biasa dikenal dengan proses pelepasan daya (discharging) [1]

Masuknya kendaraan listrik sebagai beban dalam sistem kelistrikan dapat memberikan dampak positif dan negatif terhadap sistem. Dampak negatif masuknya kendaraan listrik adalah naiknya beban puncak [2]-[4] dan memburuknya kualitas daya [5]-[7]. Namun, kendaraan listrik juga dapat memberikan dampak positif jika dikelola dengan baik, terutama jika kendaraan listrik beroperasi dalam mode V2G. Pada mode V2G, kendaraan listrik dapat berfungsi sebagai Distributed Generation (DG) dalam jumlah yang banyak dan tersebar di berbagai tempat, sehingga kendaraan listrik dapat digunakan untuk mengurangi beban puncak harian [8]-[10], sebagai pengatur frekuensi [11]-[13], sebagai pengatur tegangan [14][16], dan sebagai VAR compensator [17]-[19].

Indonesia adalah negara kepulauan terluas di dunia dan merupakan negara berpenduduk terbanyak keempat di dunia. Banyaknya jumlah penduduk di Indonesia menyebabkan banyaknya penggunaan kendaraan bermotor sebagai alat transportasi. Hingga saat ini, hampir semua kendaraan bermotor di Indonesia masih menggunakan bahan bakar minyak sebagai sumber energi. Cepat atau lambat, penggunaan kendaraan listrik juga akan masuk dan berkembang di Indonesia. Peralihan dari penggunaan kendaraan berbahan bakar minyak menjadi kendaraan listrik akan memberikan dampak terhadap sistem ketenagalistrikan di Indonesia, terutama pada pulau Jawa yang merupakan pulau dengan jumlah penduduk dan jumlah kendaraan terbanyak di 


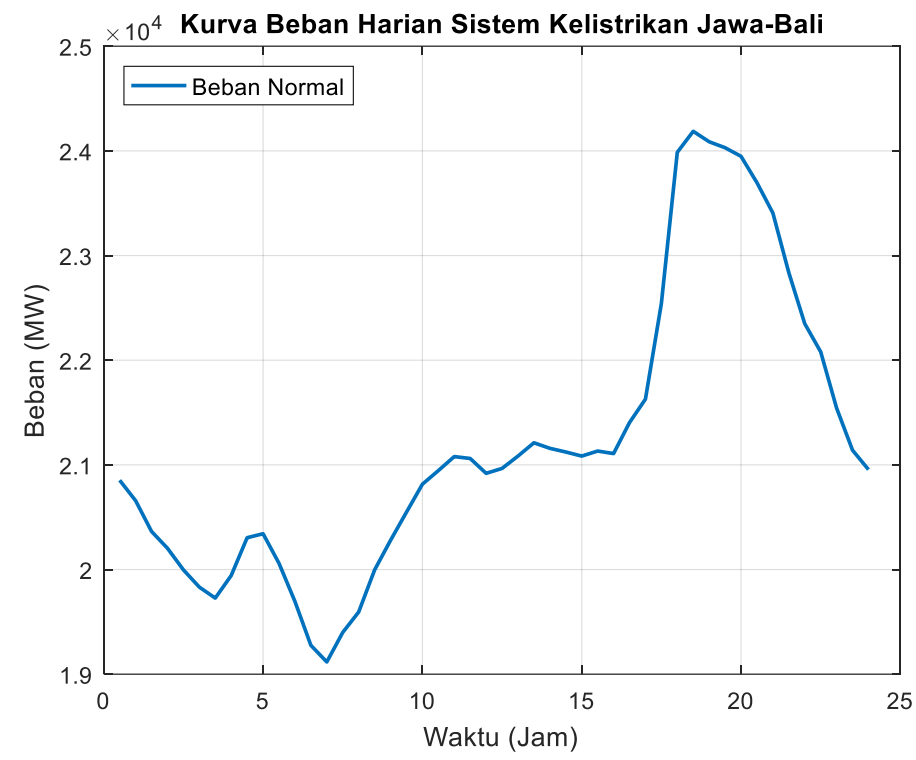

Gbr. 1 Kurva beban harian sistem kelistrikan Jawa-Bali.

TABEL I

JUMLAH MoBIL PENUMPANG DI PULAU JAWA DAN BALI

\begin{tabular}{|l|r|}
\hline \multicolumn{1}{|c|}{ Provinsi } & Jumlah Mobil Penumpang \\
\hline Jakarta & 3.869 .635 \\
\hline Jawa Barat & 1.456 .569 \\
\hline Jawa Tengah & 1.140 .300 \\
\hline Yogyakarta & 406.308 \\
\hline Jawa Timur & 1.444 .394 \\
\hline Banten & 190.858 \\
\hline Bali & 878.193 \\
\hline Total & 9.386 .257 \\
\hline
\end{tabular}

Indonesia. Pasokan listrik di pulau Jawa disuplai oleh sistem kelistrikan Jawa-Bali dengan daya mampu sebesar 35.942 MW [20].

Masalah pertama yang dapat terjadi pada sistem kelistrikan Jawa-Bali akibat masuknya kendaraan listrik dalam jumlah besar adalah naiknya beban yang ditanggung sistem selama kendaraan listrik terhubung ke jaringan, terutama pada waktu beban puncak. Oleh karena itu, makalah ini berkontribusi dalam mengkaji kesiapan sistem kelistrikan Jawa-Bali dalam menghadapi masuknya kendaraan listrik dan mengkaji strategi pengisian daya yang baik untuk mengurangi kenaikan beban puncak pada sistem kelistrikan Jawa-Bali akibat penetrasi kendaraan listrik.

\section{DATA}

Data-data yang diperlukan dalam makalah ini adalah kurva beban harian sistem kelistrikan Jawa-Bali, jumlah kendaraan bermotor di pulau Jawa dan Bali, spesifikasi serta persentase penjualan kendaraan listrik dari berbagai merek, dan spesifikasi alat pengisian daya.

\section{A. Kurva Beban Harian Sistem Kelistrikan Jawa-Bali}

Kurva beban harian sistem kelistrikan Jawa-Bali yang digunakan adalah data beban harian yang terekam pada 24
TABEL II

PERSENTASE PENJUALAN DAN SPESIFIKASI KENDARAAN LISTRIK

\begin{tabular}{|l|r|r|r|}
\hline \multicolumn{1}{|c|}{ Merek } & $\begin{array}{c}\text { Kapasitas } \\
\text { Baterai } \\
\text { (kWh) }\end{array}$ & $\begin{array}{c}\text { Jarak Tempuh } \\
\text { Maksimum } \\
\text { (mil) }\end{array}$ & $\begin{array}{c}\text { Persentase } \\
\text { Penjualan }\end{array}$ \\
\hline Chevrolet Volt & 16 & 35 & $32,00 \%$ \\
\hline Nissan Leaf & 24 & 73 & $32,67 \%$ \\
\hline Toyota Prius & 4,4 & 11 & $16,67 \%$ \\
\hline Tesla S & 85 & 265 & $18,67 \%$ \\
\hline
\end{tabular}

TABEL III

SPESIFIKASI ALAT PENGISIAN DAYA

\begin{tabular}{|l|r|r|r|}
\hline Charger & Tegangan (V) & Arus (A) & Daya (kW) \\
\hline Level 1 & 120 & 12 & 1,44 \\
\hline Level 2 & 240 & 30 & 7,20 \\
\hline
\end{tabular}

November 2019, yang ditunjukkan pada Gbr. 1 [20]. Terlihat dari Gbr. 1 bahwa beban puncak pada sistem kelistrikan JawaBali dimulai pukul 18.00 hingga pukul 00.00, dengan puncak beban adalah sebesar 24.187 MW.

\section{B. Jumlah Kendaraan Bermotor di Pulau Jawa dan Bali}

Jumlah kendaraan bermotor konvensional dijadikan acuan untuk menentukan jumlah penetrasi kendaraan listrik ke sistem kelistrikan Jawa-Bali. Data jumlah kendaraan konvensional yang digunakan hanya jumlah kendaraan jenis mobil penumpang [21]. Tabel I menyajikan data jumlah mobil penumpang di pulau Jawa dan Bali.

\section{Persentase Penjualan dan Spesifikasi Kendaraan Listrik}

Besar daya dan lama durasi kendaraan listrik terhubung ke sistem kelistrikan tergantung dari besarnya kapasitas baterai dan daya pengisian dari alat pengisi daya kendaraan listrik. Karena penjualan kendaraan listrik sangat jarang di Indonesia, maka data yang digunakan sebagai acuan diambil dari referensi luar negeri. Tabel II dan Tabel III menunjukkan persentase 
penjualan dan spesifikasi baterai dan alat pengisian daya kendaraan listrik [3].

Dengan mempertimbangkan besar kapasitas baterai masingmasing merek kendaraan listrik, kendaraan listrik tipe Chevrolet Volt, Nissan Leaf, dan Tesla S diasumsikan menggunakan alat pengisi daya level 2 dengan besar daya 7,2 $\mathrm{kW}$, sedangkan tipe Toyota Prius diasumsikan menggunakan alat pengisi daya level 1 dengan besar daya $1,44 \mathrm{~kW}$.

\section{METODOLOGI}

Penetrasi kendaraan listrik sebagai jenis beban baru ke sistem kelistrikan Jawa-Bali akan menyebabkan naiknya beban harian sistem jika dibandingkan dengan beban harian saat ini. Oleh karena itu, perlu dilakukan simulasi perhitungan kenaikan beban harian sistem Jawa-Bali akibat penetrasi kendaraan listrik untuk melihat kesiapan sistem dalam menghadapi kenaikan beban puncak tersebut. Pada perhitungan kenaikan beban yang dilakukan, diasumsikan bahwa penambahan kendaraan listrik tidak menyebabkan terjadinya masalah ketidakstabilan, tidak menyebabkan masalah kelebihan pembebanan pada jaringan, dan mengabaikan kenaikan losses pada sistem, sehingga secara sederhana kenaikan beban yang terjadi adalah penjumlahan beban saat ini ditambah dengan besar beban kendaraan listrik yang masuk ke sistem pada setiap jamnya. Adapun langkah-langkah perhitungan kenaikan beban harian akibat penetrasi kendaraan listrik adalah sebagai berikut.

\section{A. Menghitung Jumlah Kendaraan Listrik yang Terhubung ke Jaringan Kelistrikan.}

Jumlah kendaraan listrik yang terhubung ke sistem kelistrikan dihitung menggunakan (1). Perhitungan dilakukan dengan berbagai level penetrasi kendaraan listrik, dimulai dari $10 \%$ hingga $100 \%$.

$$
N_{E V}=X_{\text {pen }} \times N_{\text {kendaraan }}
$$

Pada (1), $N_{E V}$ adalah jumlah kendaraan listrik yang terhubung ke sistem kelistrikan, $X_{\text {pen }}$ adalah level persentase penetrasi kendaraan listrik yang dapat diartikan sebagai persentase perubahan kendaraan konvensional yang ada menjadi kendaraan listrik, dan $N_{\text {kendaraan }}$ adalah jumlah kendaraan konvensional yang ada. Pada makalah ini, jumlah kendaraan yang digunakan sebagai referensi hanya terbatas pada jumlah mobil penumpang yang ada di pulau Jawa dan Bali.

\section{B. Menghitung Durasi Pengisian Daya}

Perhitungan durasi pengisian daya diperlukan untuk mengetahui lamanya kendaraan listrik terhubung ke sistem. Durasi tersebut dihitung menggunakan (2) sebagai berikut.

$$
D=E / C_{k}
$$

Pada (2), $E$ adalah energi yang dibutuhkan untuk pengisian daya dari nilai State of Charge (SOC) awal hingga mencapai $100 \%$ SOC dan $C_{k}$ adalah kapasitas daya pengisian dari alat pengisi daya. Energi yang dibutuhkan tersebut dapat dihitung menggunakan (3) sebagai berikut.

$$
E=(100 \%-S O C) \times B C
$$

Pada (3), SOC adalah kapasitas baterai dalam persen ketika mulai terhubung ke sistem kelistrikan dan $B C$ adalah kapasitas baterai dari masing-masing jenis kendaraan listrik. Pada skenario G2V, SOC awal saat pengisian diasumsikan sebesar $20 \%$, sedangkan pada skenario V2G, energi yang tersisa di baterai setelah penggunaan disuplai ke jaringan, sehingga SOC yang digunakan adalah SOC baterai setelah penggunaan kendaraan listrik. SOC tersebut dapat dihitung menggunakan (4) sebagai berikut.

$$
S O C=\frac{M_{T}-M_{K}}{M_{T}}
$$

Pada (4), $M_{T}$ adalah jarak tempuh maksimum dari masingmasing jenis kendaraan listrik dan $M_{K}$ adalah jarak tempuh pemakaian harian kendaraan listrik yang diasumsikan sejauh 10 mil. Dengan mempertimbangkan umur baterai, penggunaan baterai kendaraan listrik dibatasi hingga $20 \%$, yang artinya baterai tidak melakukan discharging apabila SOC lebih rendah dibandingkan batas tersebut.

\section{Menentukan Waktu Mulai Pengisian Daya.}

Waktu mulai pengisian daya sangat menentukan kenaikan beban harian pada sistem kelistrikan. Oleh karena itu, pada makalah ini disimulasikan tiga skenario pengisian daya dengan penetrasi kendaraan listrik $10 \%$ berdasarkan metode pengisian daya dan waktu mulai pengisian daya yang berbeda. Berikut ini adalah skenario yang digunakan dalam makalah ini.

1) Skenario 1: Skenario 1 adalah skenario yang mengasumsikan kendaraan listrik hanya beroperasi sebagai beban (mode $\mathrm{G} 2 \mathrm{~V}$ ) dan waktu mulai pengisian daya hanya bergantung pada perilaku pengguna kendaraan listrik (tanpa penjadwalan). Oleh karena itu, pada skenario 1, waktu mulai pengisian daya kendaraan listrik dimulai pada pukul 18.00 , dengan pertimbangan para pengguna kendaraan listrik melakukan pengisian daya sesaat setelah sampai di rumah setelah pulang dari bekerja.

2) Skenario 2: Skenario 2 adalah skenario yang mengasumsikan kendaraan listrik hanya beroperasi sebagai beban (mode G2V), tetapi dengan waktu mulai pengisian daya yang dijadwalkan. Dengan mempertimbangkan kondisi baterai yang harus dalam kondisi penuh sebelum digunakan di pagi hari, maka waktu mulai pengisian daya kendaraan listrik pada skenario 2 dijadwalkan dimulai pada pukul 00.00, kecuali untuk kendaraan listrik tipe Tesla $\mathrm{S}$ yang memiliki kapasitas baterai $85 \mathrm{~kW}$, pengisian daya tetap dimulai pada pukul 18.00 , dengan tujuan baterai kendaraan tersebut telah terisi penuh di pagi hari.

3) Skenario 3: Skenario 3 adalah skenario yang mengasumsikan kendaraan listrik dapat terhubung ke jaringan dalam mode V2G. Pada skenario ini, energi yang tersisa pada baterai setelah penggunaan harian digunakan untuk menyuplai sistem selama waktu beban tinggi, yaitu dari pukul 18.00 dan berhenti jika SOC baterai mencapai 20\%. Namun, untuk merek Tesla, discharging hanya dilakukan hingga SOC baterai 


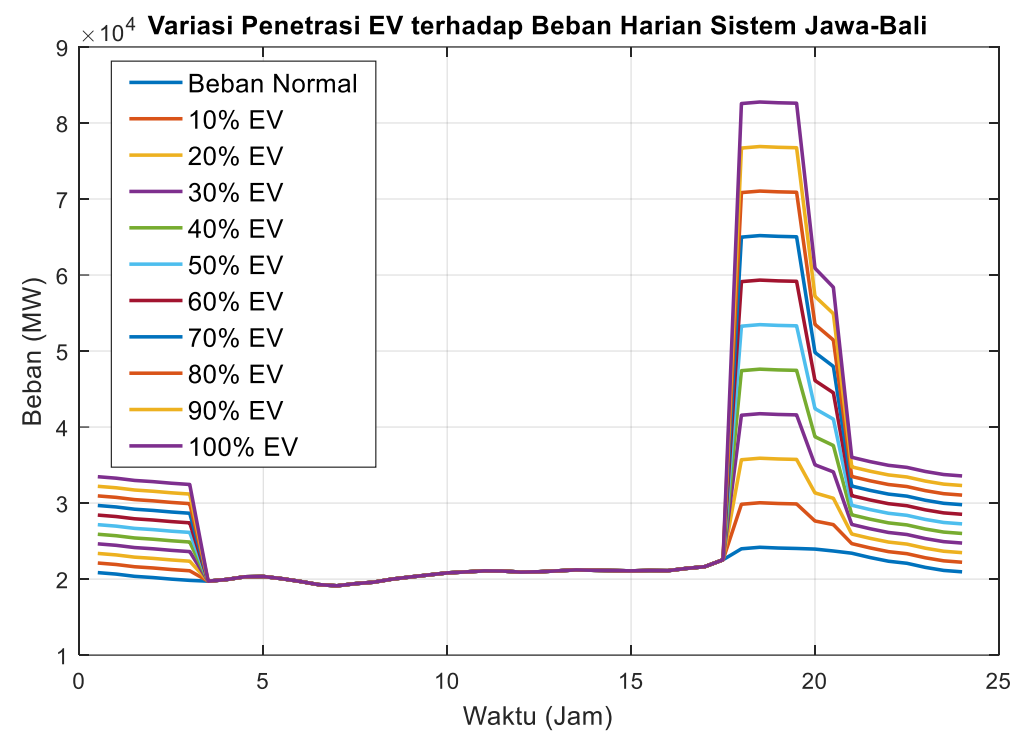

Gbr. 2 Hasil perhitungan beban harian dengan berbagai variasi level penetrasi kendaraan listrik.

mencapai $60 \%$, dengan mempertimbangkan kapasitas baterai yang besar dan agar baterai kendaraan tersebut tetap dapat terisi penuh di pagi hari, sedangkan untuk jenis Toyota Prius tidak dilakukan discharging karena baterai telah berada dibawah SOC $20 \%$ setelah pemakaian harian. Setelah mode V2G selesai, pengisian daya kendaraan listrik dijadwalkan dimulai pada pukul 00.00 saat beban mulai turun.

\section{Menghitung Kenaikan Beban Harian Akibat Penetrasi Kendaraan Listrik.}

Perhitungan $L$ atau beban harian dengan masuknya kendaraan listrik ke jaringan dilakukan dengan menambahkan $L_{0}$ atau nilai beban awal sebelum kendaraan listrik masuk ke sistem kelistrikan dengan jumlah beban tambahan dari penetrasi masing-masing merek kendaraan listrik. Perhitungan tersebut ditunjukkan pada (5).

$$
L(t)=L_{0}(t)+\sum_{\text {tipe=1 }}^{4} \alpha_{\text {tipe }} \times L_{\text {tipe }}
$$

Pada (5), $\alpha_{\text {tipe }}$ adalah persentase pemakaian kendaraan listrik tipe tertentu dan $L_{\text {tipe }}$ adalah jumlah beban tambahan dari masing-masing merek kendaraan listrik tersebut.

\section{HASIL DAN ANALISIS}

Makalah ini mengkaji kenaikan beban harian pada sistem kelistrikan Jawa-Bali dengan berbagai level penetrasi kendaraan listrik dan mengkaji strategi pengisian daya kendaraan listrik untuk mengurangi kenaikan beban tersebut. Selain itu, juga dilakukan simulasi aliran daya pada subsistem Bali untuk melihat profil aliran daya akibat penetrasi kendaraan listrik pada subsistem Bali.

\section{A. Kenaikan Beban Puncak Akibat Penetrasi Kendaraan Listrik}

Pada semua skenario yang disimulasikan, hasil simulasi perhitungan kenaikan beban harian akibat penetrasi kendaraan listrik pada sistem kelistrikan Jawa-Bali menunjukkan
TABEL IV

Beban Puncak PAda Berbagai LeVEl PENETRAsi KendaraAn LISTRIK

\begin{tabular}{|l|r|}
\hline Penetrasi Kendaraan Listrik & Beban Puncak (MW) \\
\hline Beban normal (tanpa EV) & 24.187 \\
\hline $10 \% \mathrm{EV}$ & 30.044 \\
\hline $20 \% \mathrm{EV}$ & 35.901 \\
\hline $30 \% \mathrm{EV}$ & 41.758 \\
\hline $40 \% \mathrm{EV}$ & 47.615 \\
\hline $50 \% \mathrm{EV}$ & 53.472 \\
\hline $60 \% \mathrm{EV}$ & 59.329 \\
\hline $70 \% \mathrm{EV}$ & 65.186 \\
\hline $80 \% \mathrm{EV}$ & 71.043 \\
\hline $90 \% \mathrm{EV}$ & 76.900 \\
\hline $100 \% \mathrm{EV}$ & 82.757 \\
\hline
\end{tabular}

$\mathrm{EV}=$ electric vehicle (kendaraan listrik)

kenaikan beban puncak harian ketika kendaraan listrik terhubung ke sistem kelistrikan Jawa-Bali. Namun, kenaikan beban puncak atau bentuk kurva beban harian yang terjadi berbeda untuk masing-masing skenario.

Pada skenario 1, dengan variasi level penetrasi kendaraan listrik dari $10 \%$ hingga $100 \%$, diperoleh perubahan beban harian akibat terhubungnya kendaraan listrik dalam jumlah besar seperti pada Gbr. 2. Grafik menunjukkan bahwa peningkatan beban harian sangat besar ketika seluruh tipe kendaraan listrik terhubung ke jaringan, yaitu pukul 18.0019.30. Ketika beberapa tipe kendaraan listrik telah selesai melakukan pengisian daya, terlihat beban mulai mengalami penurunan dan akhirnya dari pukul 21.00 hingga 3.30 kendaraan listrik yang terhubung ke jaringan hanya merek Tesla S yang memiliki kapasitas baterai sebesar $85 \mathrm{kWh}$.

Beban puncak yang terjadi akibat masuknya kendaraan listrik dengan berbagai level penetrasi diperlihatkan pada Tabel IV. Dari Tabel IV dapat dilihat bahwa sistem kelistrikan JawaBali yang saat ini memiliki daya mampu sebesar 35.942 MW hanya mampu menyuplai beban dengan penetrasi kendaraan 


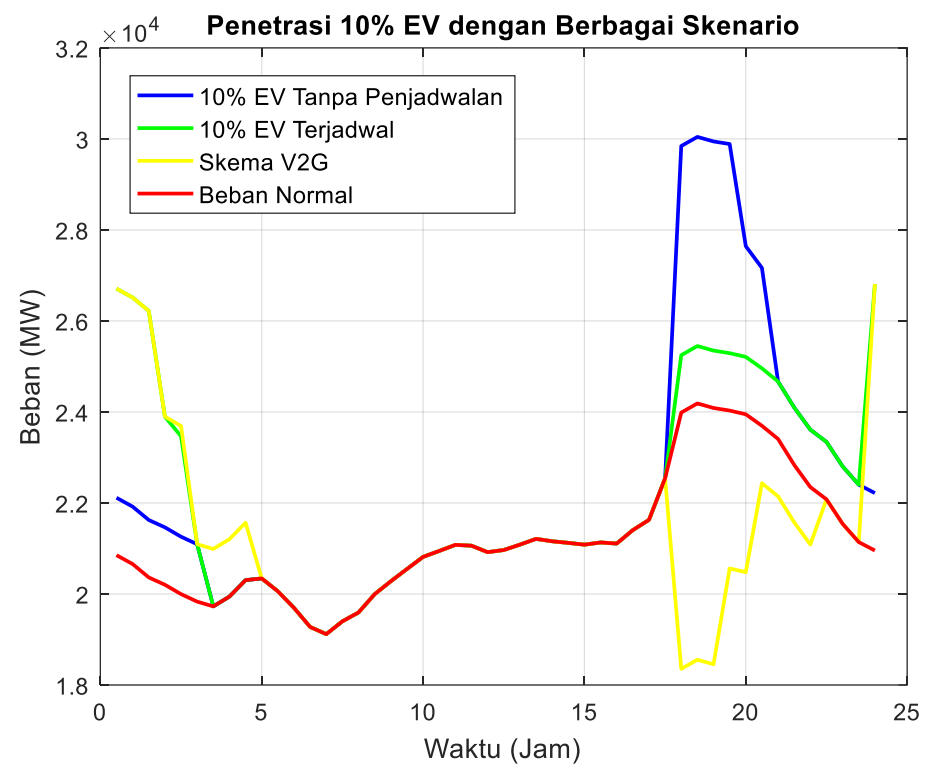

Gbr. 3 Perbandingan kurva beban harian dari berbagai skenario pada sistem Jawa-Bali.

listrik hingga $20 \%$ jika kenaikan losses pada jaringan, ketidakstabilan, dan batas pembebanan saluran diabaikan. Penetrasi kendaraan listrik yang lebih besar dari level tersebut dapat menyebabkan beberapa beban tidak dapat dilayani selama periode beban puncak.

Gbr. 3 menunjukkan perbandingan kurva beban harian pada kondisi normal, pengisian daya tidak terjadwal (skenario 1), pengisian daya terjadwal (skenario 2), dan skema V2G (skenario 3). Untuk mengurangi kenaikan beban puncak, dapat diterapkan pengisian daya terjadwal. Hal tersebut dapat dilakukan dengan berbagai cara, salah satunya adalah dengan memberikan harga listrik yang murah pada jam-jam tertentu saat beban harian sedang rendah. Dari Gbr. 3 dapat dilihat bahwa dengan menggunakan skema pengisian daya terjadwal, kenaikan beban puncak sistem setelah penetrasi $10 \%$ kendaraan listrik dapat dikurangi. Pada saat penetrasi kendaraan listrik 10\% tanpa skema pengisian daya terjadwal, beban puncak harian adalah sebesar 30.044 MW, tetapi dengan menggunakan skema pengisian daya terjadwal, beban puncak harian hanya sebesar 26.812 MW. Selain melakukan penjadwalan pengisian daya, jika kendaraan listrik dapat terhubung ke jaringan dalam mode V2G, maka kendaraan listrik juga dapat digunakan sebagai DG untuk menyuplai dan mengurangi beban sistem pada jam-jam tertentu. Dengan menerapkan skema V2G, kendaraan listrik dapat mengurangi beban yang ditanggung sistem. Pada Gbr. 3, ketika kendaraan listrik beroperasi dalam mode V2G, yaitu pada pukul 18.00 hingga 22.30 , beban yang ditanggung oleh sistem Jawa-Bali berkurang dibandingkan dengan beban normal, karena kendaraan listrik juga bertindak sebagai DG yang menyuplai daya ke sistem. Perbandingan beban puncak yang terjadi pada masing-masing skenario ditunjukkan pada Tabel $\mathrm{V}$ dan perbandingan energi yang disuplai oleh pembangkit sistem ke beban pada berbagai skenario ditunjukkan pada Tabel VI.

Tabel V menunjukkan bahwa penetrasi kendaraan listrik ke sistem dapat menaikkan beban puncak harian dari sistem Jawa-
TABEL V

Beban Puncak Berbagai Skenario Dengan 10\% Penetras KENDARAAN LISTRIK

\begin{tabular}{|l|c|}
\hline \multicolumn{1}{|c|}{ Skenario } & $\begin{array}{c}\text { Beban Puncak } \\
\text { (MW) }\end{array}$ \\
\hline Beban normal & 24.187 \\
\hline $10 \%$ EV dengan Pengisian daya tidak terjadwal & 30.044 \\
\hline $10 \%$ EV dengan pengisian daya terjadwal & 26.812 \\
\hline $10 \%$ EV dengan Skema V2G & 26.812 \\
\hline
\end{tabular}

$\mathrm{EV}=$ electric vehicle (kendaraan listrik)

TABEL VI

BESAR ENERGI YANG DiSUPLAI SISTEM SELAMA 24 JAM PADA BERBAGAI SKENARIO DENGAN 10\% PENETRASI KENDARAAN LISTRIK

\begin{tabular}{|l|r|}
\hline \multicolumn{1}{|c|}{ Skenario } & \multicolumn{1}{|c|}{$\begin{array}{c}\text { Energi } \\
\text { (MWh) }\end{array}$} \\
\hline Beban normal & 508.843 \\
\hline $10 \%$ EV dengan Pengisian daya tidak terjadwal & 532.969 \\
\hline $10 \%$ EV dengan pengisian daya terjadwal & 532.969 \\
\hline $10 \%$ EV dengan Skema V2G & 512.335 \\
\hline
\end{tabular}

$\mathrm{EV}=$ electric vehicle (kendaraan listrik)

Bali. Namun, jika dikelola dengan benar, kenaikan beban puncak tersebut dapat dikurangi. Dengan menggunakan skenario pengisian daya terjadwal dan skenario $\mathrm{V} 2 \mathrm{G}$, beban puncak harian sistem Jawa-Bali setelah $10 \%$ penetrasi kendaraan listrik dapat dikurangi sebesar 3.232 MW.

Tabel VI menunjukkan bahwa penetrasi kendaraan listrik $10 \%$ ke sistem Jawa-Bali menyebabkan naiknya energi harian yang disuplai sistem sebesar 23.495 MWh jika dibandingkan dengan beban normal, baik untuk pengisian daya tidak terjadwal ataupun pengisian daya terjadwal. Kedua skenario ini menyerap energi harian dari sistem dalam jumlah yang sama besar. Hal itu dikarenakan pada skenario 2 hanya dilakukan penggeseran jadwal pengisian daya pada jam dengan beban yang lebih rendah. Namun, dengan menggunakan skema V2G (skenario 3), energi yang disuplai oleh sistem dapat berkurang, 


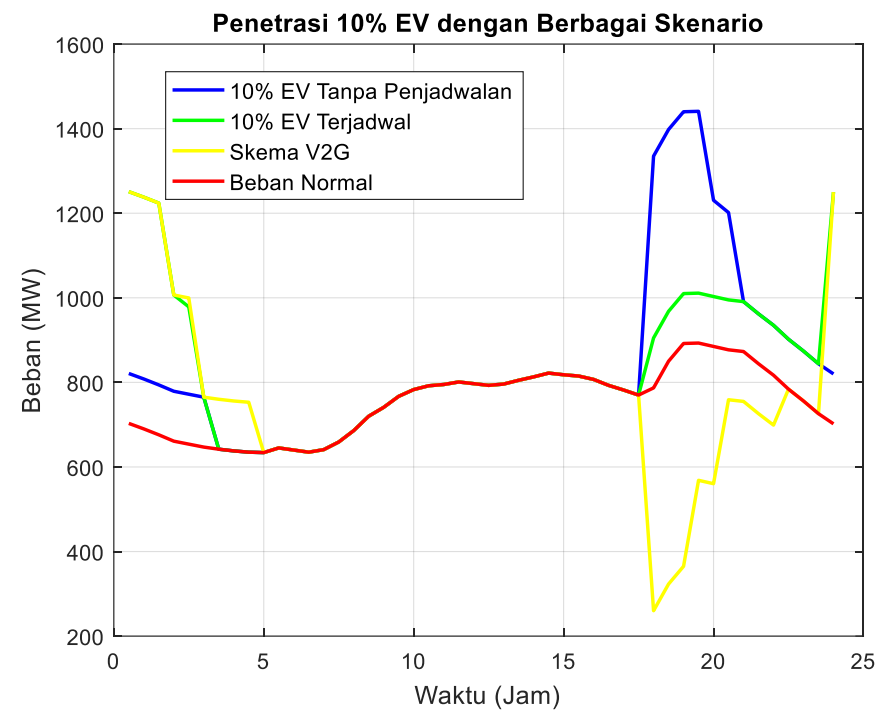

Gbr. 4 Perbandingan kurva beban harian subsistem Bali dari ketiga skenario.

karena pada jam-jam tertentu kendaraan listrik juga bertindak sebagai DG dan menyuplai daya ke sistem. Energi yang disuplai sistem menggunakan skema V2G dapat berkurang hingga 20.003 MWh dibandingkan dengan beban pada skenario 1 dan 2.

\section{B. Analisis Aliran Daya Akibat Penetrasi Kendaraan Listrik}

Penetrasi kendaraan listrik pada sistem tenaga menyebabkan naiknya beban pada sistem. Kenaikan beban tersebut menyebabkan perubahan pada aliran daya. Semakin besar beban, semakin besar pula daya yang mengalir pada saluran. Hal ini menyebabkan naiknya rugi-rugi daya pada saluran, naiknya pembebanan pada saluran, dan memperbesar drop tegangan pada sistem. Oleh karena itu, penting untuk menganalisis aliran daya pada sistem akibat penetrasi kendaraan listrik. Analisis aliran daya pada makalah ini dilakukan menggunakan perangkat lunak DIgSILENT dan dibatasi hanya dilakukan pada subsistem Bali sebagai sampel untuk melihat pengaruh strategi pengisian daya terhadap profil aliran daya.

Subsistem Bali adalah bagian dari sistem kelistrikan JawaBali. Subsistem Bali tersebut mempunyai pembangkit regional yang memiliki daya mampu sebesar 946,6 MW ditambah dengan pasokan daya dari Jawa melalui kabel laut Jawa-Bali dengan daya mampu $340 \mathrm{MW}$, sehingga total daya mampu pada subsistem Bali adalah 1.286,6 MW [22]. Analisis aliran daya dilakukan pada kondisi terburuk, yaitu kondisi beban puncak. Berdasarkan skenario strategi pengisian daya sebelumnya, dengan melakukan langkah-langkah yang sama, diperoleh perubahan kurva beban harian subsistem Bali pada tanggal 24 November 2019 seperti pada Gbr. 4.

Dari Gbr. 4 dapat dilihat bahwa beban puncak pada sistem Bali pada kondisi normal adalah sebesar 893 MW. Apabila $10 \%$ dari jumlah mobil penumpang di Bali berubah menjadi kendaraan listrik dengan pengisian daya tanpa penjadwalan yang benar, subsistem Bali akan memperoleh kenaikan beban puncak sebesar $548 \mathrm{MW}$, sehingga beban puncak pada subsistem Bali tanpa melakukan penjadwalan pengisian daya menjadi 1.441 MW. Sedangkan jika pengisian daya kendaraan listrik diatur ketika beban rendah, kenaikan beban puncak hanya sebesar $358 \mathrm{MW}$ atau beban puncak hanya meningkat menjadi 1.251 MW. Perbedaan nilai beban puncak ini memberikan perbedaan pada profil aliran daya pada subsistem Bali. Oleh karena itu, dilakukan analisis aliran daya pada subsistem Bali dengan tiga kondisi beban puncak tersebut menggunakan perangkat lunak DIgSILENT. Pemodelan dilakukan dengan asumsi kenaikan beban terjadi secara merata pada tiap titik beban, sehingga beban pada tiap titik beban yang baru dapat dihitung dengan mengalikan beban tiap titik beban lama dengan rasio antara beban puncak setalah penetrasi kendaraan listrik dan beban puncak normal. Jika dijumlahkan, total beban akan sama dengan nilai beban puncak yang baru. Hasil simulasi analisis aliran daya pada ketiga kondisi beban puncak yang berbeda tersebut ditunjukkan pada Tabel VII.

Dari Tabel VII dapat dilihat bahwa pada kondisi beban normal dengan dispatch pembangkit maksimum sebesar daya mampu, subsistem Bali masih dapat menyuplai daya ke sistem Jawa sebesar 34,6 MW. Pada saat penetrasi 10\% kendaraan listrik tanpa penjadwalan pengisian daya, subsistem Bali kekurangan daya pembangkitan regional untuk memenuhi beban, sehingga memerlukan pasokan daya dari sistem Jawa sebesar 598,58 MW. Dengan dilakukan penjadwalan pengisian daya, subsistem Bali hanya memerlukan pasokan daya dari sistem Jawa sebesar 365,09 MW. Walaupun demikian, kedua skenario penetrasi kendaraan listrik tersebut memerlukan pasokan daya dari sistem Jawa melebihi batas kemampuan saluran transmisi Jawa-Bali yang hanya sebesar $340 \mathrm{MW}$ Namun, jika ingin dilakukan penambahan saluran pasokan dari Jawa, skenario dengan penjadwalan akan membutuhkan lebih sedikit penambahan saluran dibandingkan skenario tanpa penjadwalan.

Dari Tabel VII juga diketahui bahwa rugi-rugi daya pada subsistem Bali mengalami peningkatan yang signifikan akibat penetrasi kendaraan listrik. Rugi-rugi daya pada kondisi beban 
TABEL VII

RANGKUman Hasil Simulasi AliRAn DAYA PADA PERANGKAT LUNAK DigSiLENT

\begin{tabular}{|l|r|r|r|l|}
\hline \multicolumn{1}{|c|}{ Parameter yang Diamati } & \multicolumn{1}{|c|}{$\begin{array}{c}\text { Beban } \\
\text { Normal }\end{array}$} & \multicolumn{1}{c|}{$\begin{array}{c}\mathbf{1 0 \%} \text { EV } \\
\text { Tanpa } \\
\text { Penjadwalan }\end{array}$} & \multicolumn{1}{c|}{$\begin{array}{c}\text { 10\% EV } \\
\text { dengan } \\
\text { Penjadwalan }\end{array}$} & Satuan \\
\hline Daya beban & 893,00 & $1.441,00$ & $1.251,00$ & MW \\
\hline Rugi-rugi daya & 18,93 & 104,08 & 60,60 & MW \\
\hline Total beban sistem & 911,93 & $1.545,08$ & $1.311,60$ & MW \\
\hline Pembangkitan daya regional & 946,5, & 946,50 & 946,50 & MW \\
\hline Transfer daya dari grid Jawa & $-34,6$, & 598,58 & 365,09 & MW \\
\hline Jumlah bus bertegangan di luar batas toleransi & 0,00 & 0,00 & 0,00 & Bus \\
\hline Jumlah pembebanan saluran yang melebihi 100\% & 0,00 & 2,00 & 0,00 & Saluran \\
\hline
\end{tabular}

$\mathrm{EV}=$ electric vehicle (kendaraan listrik)

normal sebesar 18,93 MW naik menjadi 104,08 MW saat penetrasi $10 \%$ kendaraan listrik tanpa penjadwalan pengisian daya. Dengan diberlakukannya penjadwalan pengisian daya, rugi-rugi daya dapat berkurang menjadi 60,6 MW. Namun, untuk ketiga skenario tersebut, baik kondisi normal, kondisi penetrasi $10 \%$ kendaraan listrik tanpa penjadwalan pengisian daya, maupun kondisi dengan penjadwalan, tidak terjadi penurunan tegangan hingga melebihi batas toleransi $( \pm 5 \%)$. Hal ini terjadi karena capacitor bank yang terdapat di subsistem masih mampu mengembalikan tegangan ke dalam batas toleransi.

Dari Tabel VII diketahui pula bahwa pada pembebanan saluran transmisi di dalam subsistem Bali saat kondisi normal tidak ada saluran yang terbebani melebihi $100 \%$ dari kemampuannya. Pada kondisi penetrasi 10\% kendaraan listrik, terdapat dua saluran yang melebihi $100 \%$ dari kemampuan pembebanannya dan dua saluran yang memiliki pembebanan lebih dari $80 \%$. Dengan melakukan penjadwalan pada pengisian daya, pembebanan pada jaringan dapat berkurang, sehingga tidak ada saluran yang terbebani lebih dari 100\%, tetapi hanya terdapat dua saluran yang memiliki pembebanan sebesar 83,59\%. Dengan demikian, dapat disimpulkan bahwa penjadwalan pengisian daya dapat memberikan dampak yang baik pada profil aliran daya sistem, khususnya pada subsistem Bali dalam makalah ini.

\section{KESIMPULAN}

Setelah melakukan simulasi perhitungan kenaikan beban harian akibat penetrasi kendaraan listrik ke sistem kelistrikan Jawa-Bali dengan tiga skenario pengisian daya, dapat ditinjau bahwa semakin besar penetrasi kendaraan listrik ke sistem, semakin besar kenaikan beban harian sistem. Selain itu, jika masalah losses, ketidakstabilan, dan pembebanan saluran diabaikan, kondisi sistem kelistrikan Jawa-Bali saat ini hanya sanggup menyediakan daya untuk beban harian ditambah dengan penetrasi kendaraan listrik sebesar 20\%. Namun, dengan menggunakan pengisian daya terjadwal, besarnya beban puncak sistem dapat dikurangi, contohnya pada kasus penetrasi kendaraan listrik sebesar $10 \%$, yaitu beban puncak dapat dikurangi sebesar 3.232 MW dengan melakukan pengisian daya secara terjadwal ketika beban rendah. Sementara itu, penggunaan skema V2G (skenario 3), selain dapat mengurangi beban puncak, juga dapat mengurangi energi yang disuplai oleh pembangkit di sistem. Pada penetrasi kendaraan listrik sebesar $10 \%$, skema V2G dapat mengurangi energi yang disuplai sistem sebesar 20.003 MWh dibandingkan dengan beban pada skenario 1 dan 2 .

Hasil simulasi aliran daya pada subsistem Bali menunjukkan bahwa penetrasi kendaraan listrik sebesar $10 \%$ pada subsistem Bali menyebabkan subsistem Bali mengalami kekurangan daya mampu untuk menyuplai beban, terjadi kenaikan losses secara signifikan, dan terdapat beberapa saluran yang memiliki pembebanan lebih dari $100 \%$. Namun, permasalahanpermasalahan pada subsistem Bali di atas dapat dikurangi dengan mengelola jadwal atau metode pengisian daya kendaraan listrik dengan baik.

\section{REFERENSI}

[1] A. Verma dan B. Singh, "Bi-Directional Charger for Electric Vehicle with Four Quadrant Capabilities," 2016 IEEE 7th Power India International Conference, 2016, hal. 1-6.

[2] I.S. Bayram, "A Stochastic Simulation Model to Assess the Impacts of Electric Vehicle Charging on Power Generation: A Case Study for Qatar," 2019 IEEE Transportation Electrification Conference and Expo, 2019, hal. 1-5.

[3] A. Almutairi, A. Bin Humayd, dan M.M.A. Salama, "Quantifying the Impact of PEV Charging Loads on the Reliability Performance of Generation Systems," 2016 IEEE Power and Energy Society General Meeting, 2016, hal. 1-5.

[4] F.H. Malik dan M. Lehtonen, "Analysis of Power Network Loading Due to Fast Charging of Electric Vehicles on Highways," 2016 Electric Power Quality and Supply Reliability, 2016, hal. 101-106.

[5] M. Di Paolo, "Analysis of Harmonic Impact of Electric Vehicle Charging Impact on the Electric Power Grid," 2017 IEEE Green Energy and Smart Systems Conference, 2017, hal. 1-5.

[6] A.K. Karmaker, S. Roy, dan M.R. Ahmed, "Analysis of the Impacts of Electric Vehicle Charging Station in Bangladesh," 2019 International Conference on Electrical, Computer and Communication Engineering, 2019, hal. 1-6.

[7] D.R. Pinto, V.T. Arioli, G.R.T. Hax, R.T. Borges, dan W.W. Teixeira, "Analysis of the Impact on Power Quality During the Recharge of Electric Vehicles and Vehicle-to-Grid Functionality," 2017 IEEE PES Innovative Smart Grid Technologies Conference Europe, 2017, hal. 1-6.

[8] Q. Dang, "Electric Vehicle (EV) Charging Management and Relieve Impacts in Grids," 2018 9th IEEE International Symposium on Power Electronics for Distributed Generation Systems, 2018, hal. 1-5.

[9] M.M. Rahman, E.A. Al-Ammar, H.S. Das, dan W. Ko, "Technical Assessment of Plug-In Hybrid Electric Vehicle Charging Scheduling for Peak Reduction," 2019 10th International Renewable Energy Congress, 2019, hal. 1-5.

[10] K. Mahmud, S. Morsalin, M.J. Hossain, dan G.E. Town, "Domestic PeakLoad Management Including Vehicle-to-Grid and Battery Storage Unit 
Using an Artificial Neural Network," 2017 IEEE International Conference on Industrial Technology, 2017, hal. 586-591.

[11] F. Sanchez, F. Gonzalez-Longatt, dan D. Bogdanov, "Impact Assessment of Frequency Support by Electric Vehicles: Great Britain Scenario 2025," 2018 20th International Symposium on Electrical Apparatus and Technologies, 2018, hal. 1-4.

[12] M.P. Jadhav dan V.N. Kalkhambkar, "Frequency Regulation by Electric Vehicle," 2018 International Conference on Current Trends towards Converging Technologies, 2018, hal. 1-6.

[13] R. Wei, Z. Liu, K. Zhou, L. Xu, dan B. Xu, "Frequency Control in Distribution Feeders based on Bidirectional V2G Converter for EV,' 2017 IEEE Conference on Energy Internet and Energy System Integration, 2017, hal. 1-5.

[14] T.H. Mohamed dan A.M.M. Abdel-Rahim, "Single Area Power System Voltage and Frequency Control Using V2G Scheme," 2017 19th International Middle-East Power Systems Conference, 2017, hal. 971975.

[15] T.H. Mohamed dan H.A. Hassan, "Terminal Voltage and Power Regulation Using Vehicle-to-Grid (V2G) Schemes Connected to a TwoArea Power System," 2018 20th International Middle East Power Systems Conference, 2019, hal. 203-208.

[16] S. Dinkhah, C.A. Negri, M. He, dan S.B. Bayne, "V2G for Reliable
Microgrid Operations: Voltage/Frequency Regulation with Virtual Inertia Emulation," 2019 IEEE Transportation Electrification Conference and Expo, 2019, hal. 1-6.

[17] M. Latifi, R. Sabzehgar, dan M. Rasouli, "Reactive Power Compensation Using Plugged-in Electric Vehicles for an AC Power Grid," 2018 44th Annual Conference of the IEEE Industrial Electronics Society, 2018, hal. 4986-4991.

[18] M. Latifi, R. Sabzehgar, M. Rasouli, dan P. Fajri, "Active and Reactive Power Compensation Using a PEV-based Three-level Capacitor Clamped Inverter," 2019 IEEE Texas Power and Energy Conference, 2019, hal. 16.

[19] J.U. Ugwuanyi, Y.P. Chan, K.H. Loo, dan Y.M. Lai, "Three-port ac-dc Bidirectional Converter with V2G Reactive Power Support," 2017 IEEE Power and Energy Conference at Illinois, 2017, hal. 1-7.

[20] (2019) "Bidang Operasi Sistem P2B" [Online], https://hdks.pln-jawabali.co.id/app4/system.php, tanggal akses: 25-Nov-2019.

[21] BPS-Statistics Indonesia, Statistik Transportasi Darat, Jakarta, Indonesia: BPS-Statistics Indonesia, 2017.

[22] PT. PLN, RUPTL Rencana Usaha Penyediaan Tenaga Listrik PT. PLN (PERSERO) 2019 - 2028, Jakarta, Indonesia: PT. PLN, 2019. 